\title{
ANALISIS KEBUTUHAN (NEED ASSESSMENT) PENGEMBANGAN INSTRUMEN PENILAIAN KOMPETENSI KEPRIBADIAN GURU DI KABUPATEN KEBUMEN
}

\author{
Atim Rinawati dan Nginayatul Khasanah \\ Institut Agama Islam Nahdlatul Ulama (IAINU) Kebumen \\ e-mail: atimrinawati26@gmail.com
}

\begin{abstract}
Abstrak
Tujuan dari penelitian ini adalah untuk menggali sejauhmana kebutuhan pengembangan instrumen penilaian kompetensi kepribadian guru di Kabupaten Kebumen. Penelitian ini menggunakan metode kualitatif, dengan metode pengumpulan data berupa wawancara dan dokumentasi. Penentuan sampel digunakan metode purposive. Hasil dari penelitian ini adalah terdapat empat kesimpulan yang mendorong perlunya pengembanagn instrumen, yaitu (1) Ditemukannya dua permasalahan besar yaitu belum mampunya sebagain guru untuk menjadi role model bagi murid, serta komitmen guru dalam menjalankan tugas profesionalnya dinilai masih lemah. (2) Pengembangan instrumen penilaian kompetensi kepribadian guru sangat mendesak untuk dilaksanakan (3) Sekolah belum dapat melakukan penilaian kompetensi kepribadian guru yang sistamatis dan terukur karena belum adanya instrumen penilaian yang direkomendasikan oleh pemerintah. (4) Terdapat tiga komponen yang menjadi rekomendasi sebagai indikator yang dinilai melalui instrumen tersebut, yaitu komitmen guru dalam menjalani profesi, norma kesopanan, serta motivasi guru untuk membebaskan siswa dari kebodohan. Pendekatan profetik sangat direkomendasikan sebagai dasar dalam penyusunan instrumen kompetensi kepribadian guru.
\end{abstract}

Kata Kunci: Analisis kebutuhan, instrumen penilaian, kompetensi kepribadian guru 


\section{PENDAHULUAN}

Guru merupakan elemen kunci dalam proses pendidikan sehingga kualitas guru merupakan representasi dari kinerja serta kualitas pendidikan. Dalam proses pendidikan guru menempati garda terdepan yang menjadi inti dari semua proses pendidikan. Alcorn menyatakan bahwa kualitas suatu sistem pendidikan secara keseluruhan sangat berkaian dengan kualitas gurunya, sehingga peningkatan kualitas pendidikan harus berjalan seiring dengan peningkatan kualitas guru. ${ }^{1}$ Guru yang berkualitas merupakan syarat mutlak bagi tercapainya pendidikan yang berkualitas. Begitu pula sebaliknya apabila apabila masih terdapat masalah berkaitan dengan kualitas guru maka kualitas hasil pendidkan tidak tercapai sebagaimana mestinya.

Kegiatan pembelajaran merupakan inti dari proses pendidikan. Berkaitan dengan sangat pentingnya peran guru dalam kegaiatan pembelajaran, Zamronimengatakan bahwa guru merupakan sumber ilmu dan ketrampilan. Kehadirannya di muka kelas merupakan kondisi mutlak yang harus ada agar proses belajar mengajar berlangsung dengan baik. ${ }^{2}$ Guru adalah elemen yang sangat dominan dalam kegiatan pembelajaran dan tidak dapat tergantikan oleh teknologi secanggih apapun. Perkembangan teknologi dalam bidang pendidikan yang terwujud dengan beraneka ragamnya media pembelajaran dan alat bantu pembelajaran tidak lantas mampu menggantikan kehadiran guru di dalam kelas. Segala bentuk hasil teknologi tersebut sebatas berfungsi sebagai pendukung guru untuk menghasilkan kualitas pembelajaran yang baik. Siswa membutuhkan unsur-unsur manusiawi yang langsung diperoleh dari kehadiran guru di dalam kelas, seperti sikap, nilai, parasaan, karakter dan kepribadian yang tidak dapat secara maksimal diperoleh dari teknologi.

Peran dan tanggung jawab guru yang begitu besar dalam proses pendidikan mendorong pemerintah untuk meningkatkan dan mengembangkan kualitas guru di Indonesia. Diterbitkannya Undang-Undang Nomor 14 tahun 2005 tentang Guru dan Dosen adalah langkah nyata upaya pemerintah untuk terus memperbaiki kualitas guru. Salah satu isi dari peratutan tersebut adalah diharuskannya guru memiliki empat kompetensi, yaitu kompetensi pedagogis, kompetensi kepribadian, kompetensi sosial dan kompetensi profesional.

\footnotetext{
$1 \quad$ Alcorn, To the Fullest Extent of His Power: Ce Beeby's Life in Education, (Wellington: Victoria University Press, 1999), hlm. 23.

2 Zamroni, Paradigma Pendidikan Masa Depan, (Yogyakarta: Bigraf Publishing, 2000), hlm.5.
} 
Beberapa program pemerintah telah dicanangkan sebagai konsekuensi adanya UU tersebut. Sertifikasi profesi guru sebagai suatu rangkaian proses menuju terwujudnya profesionalime guru sudah berlangsung sejak tahun 2007 dan hingga saat ini terus mengalami perbaikan. Pelaksanaan Uji Kompetensi Guru (UKG) dan Program Pendidikan dan Latihan Guru (PLPG) merupakan prasyarat guru memperoleh sertifikat profesi yang semestinya sudah merepresentasikan terpenuhinya keempat kompetensi yang dipersyaratkan pada kenyataannya belum sepenuhnya merepresentasikan terpenuhinya kompetensi pedagogis, kepribadian, sosial, dan profesional guru. Materi uji kompetensi guru yang dilaksanakan secara online berbentuk objektif test mencakup 30\% instrumen tes kompetensi pedagogik dan $70 \%$ instumen tes kompetensi profesional. Artinya kompetensi kepribadian dan kompetensi sosial belum mendapatkan prioritas penanganan oleh pemerintah. Kenyataan ini tentu menjadi permasalahan tersendiri karena aspek kepribadian guru memiliki peranan yang sangat penting pengaruhnya terhadap keberhasilan proses pendidikan.

Menurut Atkinson kepribadian adalah segala bentuk pola pikiran, emosi, dan perilaku yang berbeda dan merupakan karakteristik yang menentukan gaya personal individu dan mempengaruhi interaksinya dengan lingkungan. Kepribadian merupakan pola-pola perilaku asli yang menetap dalam diri individu. ${ }^{3}$ Gaya personal dalam kehidupan sehari hari selama berinteraksi dengan orang lain merupakan manivestasi dari keribadian seseorang yang didasarkan pada pola pikiran dan emosi. Seseorang yang memliki pola pikir positif akan memiliki gaya personal yang baik di hadapan orang lain, yang tercermin dalam kata-kata dan perilaku. Begitu pula orang yang dapat mengolah emosi, sebagai contoh dapat memenej hati, pikiran dan ucapan juga akan diraakan orang lain sebagai sosok yang memiliki kepribadian baik.

Dalam kontek kepribadian Mulyasa menyatakan bahwa pribadi guru sangat berperan dalam membentuk pribadi siswa. ${ }^{4}$ Guru yang dalam keseharian berperilaku baik seperti disiplin, ramah, sopan dalam berpenampilan dan bertutur, serta solutif terhadap permasalahan yang dihadapi siswa dikatakan memiliki kepribadian yang baik atau memiliki akhlak yang mulia. Sebaliknya guru berperilaku tidak baik atau tidak menyenangkan bagi siswa dan lingkungan sekolah seperti sering terlambat masuk kelas, mudah marah, berkata dengan

\footnotetext{
Atkinson, Pengantar Psikologi, terj. Nurdjanah Taufik, dkk, (Jakarta: Erlangga, 1998), hlm.202.

4 M. Mulyasa, Standar Kompetensi Sertifikasi Guru, (Bandung: Remaja Rosdakarya, 2007), hlm.117.
} 
nada keras dan kurang bisa mengontrol emosi serta kurang peduli terhadap permasalahan yang dihadapi siswa akan mendapat label guru yang memiliki kepribadian kurang baik.

Kebribadian guru sering kali dijadikan parameter tinggi atau rendahnya kewibawaan guru di mata peserta didik maupun masyarakat. ${ }^{5} \mathrm{Guru}$ yang memiliki kepribadian baik secara tidak langsung akan menjadikan murid menghormati dan menghargai sehingga menghadirkan semangat tersendiri untuk mengikuti kegiatan pembelajaran. Penghormatan dari seorang murid kepada gurunya sangat berpengaruh terhadap keberhasilan kegiatan pembelajaran. Begitu pula sebaliknya, apabila murid sudah memiliki pandangan kurang baik terhadap gurunya sebagai contoh guru yang mudah marah, dan tidak menghargai waktu akan menimbulkan rasa tidak suka dalam diri murid. Hal tersebut dapat dipastikan memicu kurang maksimalnya kualitas pembelajaran yang di dalamnya terdapat proses transver ilmu dan nilai.

Beberapa penelitian tentang kompetensi kepribadian guru sudah pernah dilakukan, diantaranya penelitian Een Khaeruniah yang berjudul "Effects of Perceived Teacher Personality on Student Class Evaluations: A Comparison between Japanese Instructors and Native English Speaking Instructors." Penelitian ini bertujuan untuk mengetahui sejauh mana kontribusi kepribadian guru terhadap motivasi serta disiplin siswa khususnya pada Mata Pelajaran Fiqih di MTs Negeri Cikanjung, Bandung, Jawa Barat. Penelitian ini menggunakan metode kuantitatif jenis eksperimen Hasil dari penelitian ini adalah bahwa kompetensi kepribadian seorang guru memiliki kontribusi terhadap motivasi belajar siswa. Pengaruh kompetensi kepribadian guru terhadap memotivasi siswa sebesar 46,1\%, kompetensi kepribadian guru mempengaruhi disiplin siswa sebesar $51,7 \%$ dan ada hubungan yang signifikan antara motivasi dan disiplin siswa sebesar $0386 .^{6}$

Penelitian mengenai kepribadian guru juga dilakukan oleh Muhammad Irfan Arif, Aqeela Rashid, Syeda Samina Tahira, dan Mahnaz Akhter dengan judul "Personality and Teaching: An investigation into Prospective Teacher's Personality."Penelitian ini bertujuan untuk mengukur dan membandingkan karakter kepribadian calon guru di lembaga pendidikan calon guru di Punjab,

5 GJ. Mouly, Psyicology for Effective Teaching. (New York: Holt, Rinehart, and Winston, 1973), hlm.2.

6 Een Kheruniah. "A Teacher Personality Competence Contribution to a Student Study Motivation and Discipline to Fiqh Lesson", inInternational Journal of Scientific \& Technology Research, Vol. 2, No.2, (2013), hlm.108-112. 
Pakistan. Pengukuran tersebut didasarkan pada the Big Five Inventory (BFI) yang dikembangkan oleh Oliver P. John dengan sedikit modifikasi, yaitu Extraversion, Agreeableness, Conscientiousness, Neuroticism and Openness (keterbukaan). Dalam penelitian ini dilibatkan sampel 100 calon guru terdiri dari 60 wanita dan 40 pria. Data yang terkumpul dianalisis dengan menggunakan teknik statistik deskriptif dan inferensial seperti mean dan uji-t. Hasil dari penelitian ini adalah kepribadian openness (keterbukaan) guru lebih domonan dibandingkan dengan empat kepribadian yang lain. Temuan yang lain adalah calon guru perempuan memiliki nilai yang lebih unggul pada lima kepribadian dibandingkan dengan calon guru laki-laki. ${ }^{7}$

Begitu besarnya pengaruh kompetensi kepribadian guru terhadap kebersilan proses pendidikan serta belum adanya perhatian yang lebih dari pemerintah untuk melakukan penilaian sebagaimana yang telah dilakukan untuk kompetensi pedagogis dan profesional dalam Uji Kompetensi Guru (UKG) merupakan suatu tantangan serta peluang untuk menyusun perangkat penilaian kompetensi kepribadian guru melalui pengembangan instrument. Analisa kebutuhan secara nyata di lapangan atau yang dalam tahapan Penelitian dan Pengembangan (Research and Development) diistilahkan need assessment mutlak diperlukan untuk menggali informasi sejauhmana pengembangan diperlukan serta sejauhmana kemampuan pihak-pihak terkait untuk merealisasikannya. Penelitian ini dimaksudkan untuk melakukan analisa kebutuhan di lapangan berkaitan dengan kebutuhan serta kemampuan pelaku pendidikan untuk melaksanakan penelitian kompetensi kepribadian guru. Adapun aspek yang akan dikaji adalah (1)Bagaimana kondisi guru saat ini berkaitan dengan kompetensi kepribadiannya, (2) Bagaimana persepsi kepala sekolah terhadap pengembangan instrumen penilaian kompetensi kepribadian guru? (3) Bagaimana cara sekolah melakukan penilaian kompetensi kepribadian guru, dan (4) Bagaimanakah harapan terhadap instrumen penilaian kompetensi kepribadian guru yang nantinya akan dikembangkan?

\footnotetext{
Muhammad Irfan Arif, Aqeela Rashid, Syeda Samina Tahira, dan Mahnaz Akhter, "Personality and Teaching: An Investigation into Prospective Teachers' Personality", inInternational Journal of Humanities and Social Science, Vol. 2, No. 17 (2012).
} 


\section{METODE}

Penelitian ini menggunakan metode kualitatif dengan subjek penelitian Kepala Sekolah di Kabupaten Kebumen. Adapun sekolah yang dijadikan sebagai lokasi penelitian ditetapkan menggunakan purposive sampling berdasarkan status sekolah negeri/swasta, sekolah/madrasah, serta letak sekolah di pusat kota atau kota kecamatan. Penelitian dilakukan selama kurun 2 bulan yaitu selama November hingga Desember 2017. Sekolah yang ditetapkan sebagai lokasi penelitian adalah SMA Negeri 1 Klirong, SMP Negeri 1 Klirong, MTs Syafi'iyah Grogolpenatus Petanahan, SDN Munggu-Petanahan dan MI Ma'arif Adikarso Kebumen, dan SD Negeri 1 Gebansari. Teknik pengumpulan data menggunakan wawancara dan observasi sehingga instrumen penelitian yang digunakan adalah panduan wawancara dan lembar observasi. Wawancara dilakukan kepada kepala sekolah dari 6 (tujuh) sekolah tersebut. Dokumentasi data dilakukan untuk mendapatkan bukti fisik pelaksanaan penilaian kompetensi kepribadian guru yang pernah dilaksanakan di sekolah tersebut. Teknik analisa data kualitatif mengacu pada interactive model yang dirumuskan oleh Milles, Huberman dan Saldana yang terdiri atas data collection, data condensation, conclusion drawing/ verivication, dan data display. ${ }^{8}$

\section{HASIL PENELITIAN DAN PEMBAHASAN}

\section{Permasalahan Kepribadian Guru}

Berdasarkan hasil wawancara dengan 6 (enam) orang kepala sekolah dapat diidentifikasi permasalahan-permasalahan kepribadian guru yang masih terjadi hingga saat ini. Semua kepala sekolah sepakat bahwa permasalahan kepribadian guru harus ditangani dengan cepat dan tepat karena akan sangat berpengaruh terhadap kualitas hasil pendidikan siswa maupun kualitas pendidikan secara umum dalam suatu negara. Guru merupakan elemen kunci proses pendidikan sehingga baik atau buruknya kualitas guru menjadi penentu utama baik atau buruknya kualitas pendidikan.

Pertama, permasalahan kepribadian guru yang paling menjadi sorotan kepala sekolah berkaitan dengan posisi guru sebagai role model (panutan) bagi siswa. Kenyataan di lapangan pada umumnya guru belum menyadari

8 Matthew B. Miles, A.Michael Huberman, Johnny Saldana, Qualitative Data Analysis: A Method Sourcebook, (Los Angles: Sage Publication, 2014), hlm.32. 
sepenuhnya bahwa dirinya menjadi sosok yang selalu diamati bahkan ditiru oleh siswa. Berkaitan dengan hal ini, Kepala MTs Syafi[iyah Grogolpenatus secara khusus menyampaikan bahwa dalam konsep Islam, guru mestinya mampu memposisikan diri sebagai uswatun hasanah (suri tauladan yang baik). Masih banyak ditemukan guru yang dalam istilah Jawa dikatakan jarkoni, gelem ngajar ora gelem ngelakoni.Artinya, guru mau mengajar tapi tidak mau melakukan sendiri apa yang dia ajarkan. Sebagai contoh, guru dengan tegas menerapkan kedisiplinan siswa berkaitan dengan ketepatan waktu masuk kelas. Ada sanksi khusus untuk siswa yang terlambat masuk kelas, namun di waktu yang lain guru terlambat dan berulang ulang dengan berbagai macam alasan. Sikap yang seperti ini menjadikan kepercayaan serta wibawa guru di hadapan siswa menjadi turun.

Kedua, permasalahan kepribadian guru yang banyak terjadi di sekolah adalah berkaitan dengan besarnya komitmen dalam menjalankan tugas. Beberapa kepala sekolah menilai guru belum menjiwai sepenuhnya tugas yang dia emban sebagai seorang pendidik. Masih terdapat guru yang lebih cenderung menempatkan profesinya sebatas sebagai mata pencaharian untuk memperoleh pendapatan. Terlalu dangkalnya pandangan ini menjadikan guru kurang profesional dalam menjalankan tugas. Terlebih dengan begitu menggiurkannya gaji guru saat ini, khususnya untuk guru yang sudah berhak mendapatkan tunjangan profesi. Satu pernyataan yang menarik dari salah seorang kepala sekolah yang diwawancarai, bahwa sertifikasi profesi guru sebenarnya adalah proses, bukan tujuan. Sayangnya masih ada oknum guru memiliki pandangan berkebalikan, menjadikan tunjangan sertifikasi sebagai tujuan akhir segala proses pembelajaran yang dia lakukan.

Kedua permasalahan di atas menjadi sangat penting untuk segera diatasi karena menjadi dasar bagi timbulnya permasalahan yang lain. Apabila seorang guru menyadari posisinya sebagai panutan bagi siswanya maka dalam segala lini akan menjaga sikap. Guru akan senantiasa menyadari bahwa segala yang dia ucapkan, segala yang dia lakukan selalu diamati oleh murid-muridnya dan besar kemungkinan juga ditiru. Selanjutnya berkaitan dengan komitmen manakala guru sudah memiliki komitmen yang kuat dengan profesinya, menyadari secara mendasar akan tugas dan fungsinya maka akan menjauhkan diri dari hal-hal yang mestinya bukan menjadi orientasi utama. Guru akan menjalankan tugasnya dengan sepenuh hati dalam mengajar dan mendidik siswa. 


\section{Persepsi Kepala Sekolah Terhadap Pengembangan Instrumen Penilaian Kompetensi Kepribadian Guru}

Dari wawancara yang dilakukan, 6 (enam) orang kepala sekolah memiliki pandangan bahwa sangat penting dilakukan pengembangan instrumen penilaian kompetensi kepribadian guna mendapatkan seperangkan instrumen yang valid dan reliabel. Secara umum terdapat dua alasan pokok perlunya dikembangkan instrumen penilaian kompetensi kepribadian guru.

Pertama, harus segera dikembangkan instrumen penilaian kompetensi kepribadian guru mengingat pentingnya dilakukan sebuah evaluasi terhadap kepribadian guru selama ini. Evaluasi akan menghasilkan suatu kesimpulan yang tepat apabila dilakukan menggunakan alat ukur yang tepat. Karena begitu luasnya pengertian kepribadian, maka harus ditentukan dengan jelas kepribadian mana yang dimaksud. Kompetensi kepribadian harus dijabarkan dalam indikator yang tepat dan jelas sehingga tidak terjadi bias dalam hasil serta interpretasi.

Kedua, kepala sekolah berpendapat bahwa pengembangan instrumen kompetensi kepribadian guru harus segera dikembangkan mengingat belum difasilitasinya penilaian tersebut secara khusus oleh pemerintah. Tentulah hal ini menjadi permasalahan yang cukup serius mengingat dalam Undang-Undang pemerintah telah menghasruskan guru memiliki kompetensi kepribadian, akan tetapi tidak disertai alat untuk mengukur. Di tingkat satuan pendidikan sangat disadari pentingnya penilaian serta pembinaan kepribadian akan tetapi untuk saat ini belum ada upaya yang berarti mengingat belum terfasilitasinya penilaian kompetensi kepribadian tersebut.

Dari enam orang kepala sekolah yang diwawancarai satu orang kurang sepakat dengan rencana pengembangan instrumen kompetensi kepribadian guru. Alasan pertama karena dipandang sudah terlalu banyak beban administrasi yang ditanggung oleh sekolah dan guru sehingga dianggap penilaian kompetensi kepribadian akan semakin menambah beban dan menghambat tugas utama guru yaitu melakukan pembelajaran di kelas. Alasan kedua karena dipandang instrumen penilaian kepribadian cukup sulit dikembangkan mengingan kepribadian merupakan variabel yang tidak mudah untuk diukur.

\section{Penilaian Kopetensi Kepribadian Guru yang Sudah Dilaksanakan}

Berdasarkan hasil wawancara dan dokumentasi terdapat beberapa pola pelaksanaan penilaian kompetensi kepribadian yang sudah dilaksanakan di 
sekolah-sekolah di Kabupaten Kebumen mulai dari tingkatSD/MI, SMP/MTs, serta SMA/MA. Semua pola penilaian tersebut dilaksanakan secara mandiri di sekolah mengingat belum adanya instrumen penilaian kompetensi kepribadian guru yang disiapkan oleh pemerintah. Hal ini cukup menjadi hambatan bagi sekolah dalam upaya menyiapkan sumber daya guru yang berkualitas. Pada umumnya sekolah mengalami kebingungan dalam menyikapi Undang-Undang Nomer 14 Tahun 2005 yang salah satunya mempersyaratkan guru memenuhi kompetensi kepribadian. Peraturan ini senada dengan kebutuhan di lapangan berkaitan dengan perlunya peningkatan kualitas kepribadian guru secara umum. Sekolah merasa sangat perlu untuk melakukan penilaian kompetensi kepribadian guru sebagai dasar tindak lanjut pembinaan kepribadian, akan tetapi belum memiliki alat untuk menilai berupa instrumen penilaian kompetensi kepribadian guru.

Sekolah pada umumnya melakukan penilaian kompetensi kepribadian sebatas menggunakan pengamatan langsung tanpa adanya bukti tertulis. Sebagai contoh apabila didapati laporan dari siswa akan adanya guru yang dianggap melanggar norma, maka kepala sekolah akan memanggil guru tersebut untuk dilakukan pembinaan. Peran komite sekolah juga berpengaruh dalam menilai kualitas peneluhan kompetensi guru walaupun belum dapat melakukan penelitian yang detail berkaitan dengan kompetensi kepribadian. Komite sekolah sebagai mediator antara sekolah dangan wali siswa dan masyarakat tidak jarang memberikan masukan berkaitan dengan kualitas guru berdasarkan masukan dari berbagai pihak baik dari dalam maupun luar sekolah.

Sekolah swasta yang berada di bawah naungan yayasan tertentu memiliki pola yang berbeda berkaitan dengan penilaian kompetensi kepribadian guru. Pengurus yayasan memiliki pengaruh yang cukup signifikan dalam menilai kepribadian guru, walaupun penilaian baru sebatas pada pengamatan tanpa adanya laporan tertulis. Pola seperti ini dterapkan di MTs Syafi'iyah Grogolpenatus, Petanahan. Dalam pertemuan rutin antara pengurus yayasan dengan pihak sekolah sering kali dilakukan evaluasi terhadap kinerja guru termasuk dalam ranah kepribadian.

Pada intinya, sejauh pengamatan belum ditemukan sekolah yang melakukan penilaian kompetensi kepribadian guru yang sesuai dengan kaidah-kaidah penilaian. Hal ini tentu saja disebabkan karena belum adanya instrumen penilaian kompetensi kepribadain baku yang direkomendasikan atau dimandatkan oleh pemerintah. 


\section{Harapan Terhadap Konstruk Kompetensi Kepribadian yang Dikembangkan}

Dari penelitian ini diperoleh beberapa masukan berkaitan dengan pengembangan instrumen penilaian kompetensi kepribadian guru khususnya indikator kepribadian apa saja yang harus diukur. Berdasarkan pengamatan terhadap permasalahanyangmunculdilapangan, kepalasekolah menginventarisir komponen kepribadian yang perlu dinilai sehingga nantinya akan ada tindak lanjut untuk mengadakan pembinaan kepribadian guru. Komponen kepribadian guru yang sangat perlu untuk dinilai diantatanya adalah komitmen dalam menjalankan tugas dan fungsi sebagai pendidik. Teramat perlu guru dinilai seberapa besar kesungguhannya dalam menjalankan tugas mengingat profesi guru sangat berpengaruh dengan kemajuan peradaban. Diperlukan guru yang memiliki komitmen serta dedikasi tinggi dalam menjalankan tugas dan fungsinya.

Kesopanan juga menjadi indikator yang perlu dikembangkan dalam penyusunan instrumen penilaian kompetensi kepribadian guru. Kesopanan yang dimaksud adalah kesopanan dalam berbicara atau bertutur kata khususnya di hadapan murid dan kesopanan dalam berpakaian. Guru diharapkan tetap selektif dan profesional dalam memilih busana dengan semakin berkembangnya trend busana saat ini.

Motivasi dalam mengentaskan siswa dari kebodohan juga menjadi komponen yang sangat perlu diukur dan dibina berkaitan dengan pemenuhan kompetensi kepribadian. Guru harus memiliki motivasi yang kuat untuk membewa transformasi sosial siswa dari semula belum mengetahui hingga mengetahui dan mengamalkan. Motivasi seperti ini harus diimbangi dengan semangat guru untuk terus meningkatkan kualitas diri dan menyesuaikan terhadap perkembangan ilmu. Guru tidak diperbolehkan stagnan dalam belajar dan hanya mengandalkan ilmu yang mereka dapatkan dalam perkuliahan. Guru harus meningkatkan semangat literasi supaya dapat menyesuaikan terhadap perkembangan ilmu.

Saat peneliti menawarkan pendekatan profetik (kenabian) sebagai dasar pengembangan instrumen, semua informan sepakat dan menilai pendekatan tersebut sangatlah tepat untuk digunakan. Nabi Muhammad adalah manusia paling sempurna, dan guru yang paling mulia di dunia ini. Terdapat banyak karakter Muhammad dalam posisinya sebagai guru yang dapat diadopsi dan diterapkan oleh guru secara kontemporer. 


\section{KESIMPULAN}

Berdasarkan analisa kebutuhan yang dilakukan di beberapa sekolah di Kabupaten Kebumen dapat disimpulkan bahwa pengembangan instrumen penilaian kompetensi kepribadian sangat perlu untuk segera dikembangkan. Hal ini didorong karena banyaknya permasalahan yang berkaitan dengan kualitas guru pada saat ini, serta belum adanya instrumen baku yang valid dan reliabel yang direkomendasikan atau diamanatkan pemerintah untuk menilai kompetensi kepribadian. Terdapat empat kesimpulan yang mendorong perlunya pengembanagn instrumen ini, yaitu (1) Ditemukannya permasalahan yang mendasar berkaitan dengan pemenuhan kompetensi kepribadian guru, khususnya dalam dua hal yaitu guru pada umumnya belum mampu menempatkan diri sebagai role model bagi murid, serta komitmen guru dalam menjalankan tugas profesionalnya dinilai masih lemah. (2) 5 (lima) dari 6 (enam) informan menyatakan bahwa pengembangan instrumen kompetensi kepribadian guru sangat mendesak untuk segera dikembangkan dan diaplikasikan. Hal ini dilatar belakangi kondisi di lapangan berkaitan dengan pemenuhan kompetensi kepribadian guru. Belum adanya alat ukur yang valid dan reliabel menjadi kendala tersendiri khususnya bagi kepala sekolah untuk menilai kompetensi kepribadian guru. (3) Sekolah belum dapat melakukan penilaian kompetensi kepribadian guru yang sistamatis dan terukur karena belum adanya instrumen penilaian yang direkomendasikan oleh pemerintah. Pada umumnya sekolah mengadakan penilaian sederhana melalui pengamatan yang digunakan sebagai dasar pembinaan kepribadian guru. (4) Terdapat tiga komponen yang mendesak untuk segera dapat dinilai dan dibina yaitu berkaitan dengan komitmen, norma kesopanan, serta motivasi guru untuk membebaskan siswa dari kebodohan. Pendekatan profetik sangat direkomendasikan sebagai dasar dalam penyusunan instrumen kompetensi kepribadian guru.

\section{DAFTAR PUSTAKA}

Alcorn, N. (1999).To the Fullest Extent of His Power: Ce Beeby's Life in Education, Wellington: Victoria University Press.

Atkinson, (1998). Pengantar Psikologi, terj. Nurdjanah Taufik, dkk, Jakarta: Erlangga. 
Kheruniah, Een. (2013). "A Teacher Personality Competence Contribution to a Student Study Motivation and Discipline to Fiqh Lesson",in International Journal of Scientific \& Technology Research,Vol. 2, No.2.

Mouly, GJ. (1973). Psyicology for Effective Teaching. New York: Holt, Rinehart, and Winston.

Mulyasa, E. (2005). Menjadi Guru Profesional, Menciptakan Pembelajaran Kreatif dan Menyenangkan. Bandung: Remaja Rosdakarya.

Muhammad Irfan Arif, Aqeela Rashid, Syeda Samina Tahira, dan Mahnaz Akhter. (2012). "Personality and Teaching: An Investigation into Prospective Teachers' Personality", In International Journal of Humanities and Social Science, Vol. 2, No. 17.

Miles, M.B., Huberman, A.M., Saldana, J. (2014). Qualitative Data Analysis: A Method Sourcebook, (Los Angles, Sage Publication.

Undang-Undang No 14 Tahun 2005 Tentang Guru dan Dosen

Zamroni. (2000). Paradigma Pendidikan Masa Depan. Yogyakarta: Bigraf Publishing. 